\title{
THE ROLE OF FISH PREDATION AND SPATIAL HETEROGENEITY IN DETERMINING BENTHIC COMMUNITY STRUCTURE ${ }^{1}$
}

\author{
ELLEN GILINSKY ${ }^{2}$ \\ Department of Zoology, University of North Carolina, Chapel Hill, North Carolina 27510 USA
}

\begin{abstract}
The effects of predation and spatial heterogeneity on the benthic macroinvertebrates in the littoral zone of a pond were investigated in a year-long caging experiment. Bluegill sunfish stocked at three densities within the cages were used as the predator. Heterogeneity was manipulated using artificial macrophytes. The presence of plants led to increases both in species richness and in density of most macroinvertebrates. Uncovered benthic sediments had greater species richness and higher macroinvertebrate densities than did sediments covered by macrophytes, suggesting that certain benthic species, notably several chironomid groups, migrate onto the macrophytes when this habitat becomes available.

Fish predation had a significant impact on both the number of benthic species and the densities of certain benthic macroinvertebrate groups. The predatory chironomid Clinotanypus pinguis showed a strong negative response to bluegill predation, with fish exclusion resulting in higher densities throughout the year. A group of herbivorous chironomids exhibited a response to fish predation that varied over the year, with predation resulting in elevated densities in the fall and winter but reduced densities in the summer. Many of the other species found in the littoral zone showed no significant response to bluegill predation. In addition, fish predation had no significant effect on densities of most macroinvertebrates occurring on the macrophytes.

These complex responses of the various macroinvertebrates to fish predation are explainable in terms of seasonal changes in predation intensity and the importance of invertebrate vs. vertebrate predation. In the fall and winter bluegill feeding is often reduced. By concentrating on a few preferred prey (predaceous chironomid species), their feeding might alleviate competitive or predatory relationships among the macroinvertebrates and thus lead to increased densities of many species. The high bluegill feeding intensity known to occur during the summer is severe enough to limit the numbers of most invertebrate prey. As fish predation was not effective on invertebrates in the macrophytes, it seems that the added physical complexity serves as a refuge from predation.
\end{abstract}

Key words: benthos; community structure; complexity; fish; heterogeneity; macroinvertebrates; macrophytes; pond; predation; predator-prey interactions.

\section{INTRODUCTION}

Experimental studies investigating the determinants of community structure have shown that predation is one of the major organizing forces within a community (Connell 1975). The importance of predation in community composition has been well documented for freshwater zooplankton communities (Brooks and Dodson 1965, Hall et al. 1970, Dodson 1974, and others), marine rocky intertidal communities (Paine 1966, 1969, 1971, Connell 1970, Dayton 1971, and many others) and terrestrial plant communities (Harper 1969). In all cases, predation, by suppressing dominant competitive relationships, leads to increased species diversity within the community.

The results of more recent experiments in marine soft bottom communities stand in direct contrast to the above conclusion (see review article by Peterson 1979). In this type of system, investigators have found that predator exclusion leads to increases in total in-

\footnotetext{
${ }^{1}$ Manuscript received 29 July 1982; revised 9 February 1983; accepted 11 February 1983.

${ }_{2}^{2}$ Present address: Department of Biology, Virginia Commonwealth University, Richmond, Virginia 23284 and Chesapeake Bay Program, Virginia State Water Control Board, Richmond, Virginia 23230 USA.
}

faunal densities and species richness (Commito 1976 , Reise 1977, Virnstein 1977, 1979, Bell and Coull 1978).

Rather than providing definitive answers, these studies point up the complexities of community organization. The relative importance of competition and predation in the organization of communities has certainly not been settled, and it is most probable that a synthetic viewpoint of these two processes is necessary to resolve the question. In addition, environmental characteristics such as spatial and temporal heterogeneity need to be considered when dealing with organizing factors within a system.

The importance of spatial heterogeneity to the continued coexistence of both predator and prey species has been demonstrated both mathematically (Hassell and May 1973, Murdoch and Oaten 1975, Murdoch 1977) and experimentally (Huffaker 1958, Pimentel et al. 1963, Hardman and Turnbull 1974). In addition, spatial heterogeneity may add to the stability of predator-prey interactions by allowing refuge populations that are effectively safe from predation (Huffaker and Kennett 1956, Smith 1972, Murdoch and Oaten 1975). Thus heterogeneity can lead to increased species diversity within a community, and must therefore be treated as a structuring factor. 
While many ecologists have theorized on the role of spatial heterogeneity, few definitive experiments have been performed. Kohn and Leviten (1976) approached this problem by adding artificial refuges to an intertidal system, and found that both density and diversity of predatory snails increased in the more spatially complex environments. Orth (1977) and Reise (1977) have both found that marine eelgrass beds have greater densities and species richness than adjoining bare substrate, suggesting that the eelgrass acts as a refuge from physical and biological disturbances.

The specific interaction between habitat complexity and predator efficiency has been investigated in laboratory and field experiments. Ware (1972) and Hall and Hyatt (1974), in laboratory experiments dealing with trout predation, found that increased substrate complexity led to decreased predation intensity, primarily by altering the predator's searching efficiency. In field and laboratory studies on fish and shrimp predation in eelgrass and seagrass beds, Nelson (1979), Heck and Thoman (1981), and Coen et al. (1981) found that predation intensity was less in dense eelgrass stands than in sparse beds or bare habitat. These results explain the lack of predation effects found in predator exclusion experiments in Zostera beds (Reise 1977, Young and Young 1977, Peterson 1979).

In order to elucidate further these ideas on predation and heterogeneity, I investigated the effects of predation and spatial heterogeneity on benthic community structure by measuring the responses of the prey populations to variations in predation and environmental complexity. Experimental manipulations were made to determine if predation is effective in controlling community structure, and if spatial heterogeneity may alter aspects of this control.

The pond system is particularly amenable to this type of study. The use of a relatively closed system eliminates problems of animal migration and the definition of system boundaries. The littoral zone of ponds is readily accessible to sampling and lends itself to experimental manipulations. Moreover, the study of community organization in freshwater benthic systems can test the validity and generality of what is known about the structuring of communities in other environments.

While much descriptive work has been done on ponds, few rigorous experiments have been performed. The major focus of studies on the benthic community in ponds has been on the effects of fish predation on fish food organisms, mostly aquatic insect larvae. These studies have shown that the removal of fish from a pond, or the exclusion of fish from an area of a pond, often results in increased standing crops of benthic macroinvertebrates (Ball and Hayne 1952, Hayne and Ball 1956, Hruska 1961, Korinkova 1967, Kajak 1977). Macan $(1966,1977)$ found that trout predation led to the decrease of a few benthic invertebrates, but that the majority of species were unaffected by fish predation.

In their experimental study, Hall et al. (1970) did attempt to deal with the impact of fish predation on benthic community structure. They found that bluegill predation had no measurable effect on total benthic biomass, but that emergence rates of some of the major aquatic insects were greater in the absence of fish predation. However, their experiments were complicated by simultaneous manipulations of nutrients and invertebrate predators. More recently, Thorp and Bergey (1981a) have found that fish predation did not significantly affect benthic invertebrate densities or species richness in the littoral zone of a large reservoir. As their experiments involved the comparison of fish exclosures with the natural littoral bottom habitat, they had no way to assess fish densities and therefore actual predation pressure was unknown.

Little direct work has been done on the effects of varying degrees of heterogeneity in ponds. A few investigators have hinted that more species are present in vegetated than bare areas in ponds (Hruska 1961, Gerking 1962, Korinkova 1967). There has been some suggestion that rooted aquatic plants may serve as refuges from predation (Cooper 1965, Macan 1966, 1977). Crowder and Cooper (1982) have conducted experiments on how bluegill predation varies with macrophyte density in ponds; however, they considered only the response of macroinvertebrates found within the vegetation. Both Hall et al. (1970) and Thorp and Bergey $(1981 a)$ noted the abundance of aquatic macrophytes in their experimental ponds but did not deal with the impact of this added complexity to the benthic community. While these studies are suggestive, no definitive work has been done on the effect of spatial heterogeneity and its interaction with fish predation on the benthic pond community. My study examines this question through the manipulation of bluegill fish density and macrophyte cover in a pond littoral zone.

\section{Materials ANd Methods}

\section{Site description}

The study was conducted from October 1978 through September 1979 in Botany Pond, on the grounds of the North Carolina Botanical Garden in Chapel Hill, North Carolina. This 3.24-ha mesotrophic Piedmont farm pond, initially filled in February 1966, is bordered by a mixed deciduous forest to the south and west and an old field to the east. The maximum depth of the pond is $4.2 \mathrm{~m}$, but most of the pond is considerably shallower. The major fish species found in Botany Pond include bluegill (Lepomis macrochirus), pumpkinseed (Lepomis gibbosus), yellow perch (Perca flavescens), bass (Micropterus spp.), and several species of minnows.

The only well-developed littoral zone in Botany Pond 
is found at its southern end. This was the location of the study plots. This area, where depth is $<1 \mathrm{~m}$, is dominated by Typha latifolia beds along the shoreline, with Eleocharis sp. clumps in slightly deeper water. The bottom is a mixture of sand, mud, and clay, with occasional patches of benthic algae. In this area of the pond, oxygen concentrations over the year ranged from $5-10 \mathrm{mg} / \mathrm{L}$, and water temperatures ranged from $0^{\circ} \mathrm{C}$ in winter to $25^{\circ}$ in summer. No significant surface-tobottom gradient in temperature or dissolved oxygen was observed in this shallow area during the course of the study. Additional physical and chemical data on Botany Pond may be found in Meyer and McCormick (1971).

\section{Experimental design}

The experimental design involved the simultaneous manipulation of three levels of fish predation (no fish, low fish, high fish) and two levels of heterogeneity (high, low) in order to assess the impact and interaction of these two factors on the macrobenthic pond community. All combinations of the three predation treatments and two heterogeneity treatments were included in the experiment. Each treatment was replicated three times in a randomized complete block design (Sokal and Rohlf 1969) to account for possible location effects within the pond. Thus, there was a total of 18 experimental units: three predation levels $\times$ two heterogeneity levels $\times$ three replicates.

Each experimental unit consisted of a $2 \times 3 \times 1.5$ $\mathrm{m}$ topless cage enclosing the treatment. Cages were constructed of $5 \times 5 \mathrm{~cm}$ pine frames and supports with fiberglass window-screening (mesh size $6 \times 7$ squares/ $\mathrm{cm})$ stapled on all four sides. Wood strips were nailed over all staples for extra protection. This size mesh allowed for water circulation and passage of phytoplankton and zooplankton while excluding large invertebrates, fish, and other vertebrate predators. Strips of $0.95-\mathrm{mm}$ (20 guage) galvanized steel were screwed onto the bottom edges of each cage to provide a cutting edge for an effective seal into the clay substrate. Thus, each cage partitioned off an area of natural pond bottom and allowed continued oviposition and emergence of aquatic insects. The cages were placed into the pond in late March 1978.

All fish were removed from the cages by intensive seining in mid-August 1978 prior to the experimental period. Subsequently, bluegill (Lepomis macrochirus Rafinesque) ranging in total length from 40 to $60 \mathrm{~mm}$ were seined from the pond. These fish were then introduced into the cages in late August 1978 according to the various density treatments, as given below. Fish mortality in the cages was monitored for a period of 2 wk, during which time any dead fish were removed and replaced by other bluegills within the $40-60 \mathrm{~mm}$ size range. The bluegill is particularly well suited to this study, as there is ample evidence that the benthic larvae of chironomids, odonates, trichopterans and ephemeropterans comprise the majority of its diet, even for fish of the size used here (Ball 1948, Turner 1955, Gerking 1962, Flemer and Woolcott 1966, Etnier 1971, Baumann and Kitchell 1974). A low fish density of 20 bluegill per cage $\left(3.3 \mathrm{fish} / \mathrm{m}^{2}\right)$ and a high fish density of 60 bluegill per cage $\left(10 \mathrm{fish} / \mathrm{m}^{2}\right)$ were arrived at from literature values (Werner 1977, Gerking 1978, Gilinsky 1981).

Heterogeneity treatments involved the use of artificial macrophytes to increase spatial complexity and provide potential refuges from fish predation. Artificial rather than natural rooted macrophytes were used to control for potential natural variation in surface area and food quality and to provide a continual rather than seasonal spatial resource.

The design of the artificial macrophytes was modified from that of Macan and Kitching (1972). They were constructed of braided, three-strand polypropylene rope $(0.48 \mathrm{~cm}$ diameter $)$, a material that is readily colonized by periphyton and aquatic invertebrates (Macan and Kitching 1972 and E. Gilinsky, personal observation). As this type of rope can float within the water column, it mimics natural rooted macrophytes such as Typha and Eleocharis. Each rope "plant" had 5030.5 -cm lengths of braided rope attached to a $25 \times$ $25 \mathrm{~cm}$ square of flexible Vexar netting (mesh size $15 \times$ $25 \mathrm{~mm}$ ) with rubber bands. In order to weight down the plants, small rocks were wrapped in aluminum foil and tied to the underside of the mesh square. Thus, the base of the rope plant sat on top of the pond bottom (with only the two rock packets per plant actually resting in the sediment), while the individual rope strands floated in the water column.

Artificial macrophytes were placed in the pond in late August 1978 prior to the experimental period. Each heterogeneity cage contained 60 artificial plants spaced equally throughout the cage. Each artificial plant had a surface area of $46 \mathrm{~cm}^{2}$ per strand $(0.48 \mathrm{~cm}$ diameter $\times$ $30.5 \mathrm{~cm}$ length $\times 3.14 \mathrm{~cm}$ ) for a total surface area of $0.23 \mathrm{~m}^{2}$ (for all 50 strands). Thus, cages with artificial macrophytes had $13.8 \mathrm{~m}^{2}$ of plant surface area, compared to $6 \mathrm{~m}^{2}$ of bottom sediment surface area. No artificial or natural macrophytes were found in lowheterogeneity cages.

In order to consider possible caging effects, I sampled the benthic sediments and artificial macrophytes outside of the cages during the course of the experiment. While similar numbers of species were found when comparing samples from within and outside the cages, higher macroinvertebrate densities were generally found in the open pond (Gilinsky 1981). Potential explanations for these results include the possibility of less intense predation pressure outside of the cages, as the fish were not restricted to foraging in a given area. The screened cages could have interfered somewhat with oviposition. There was a larger amount of periphyton 
on the artificial macrophytes placed outside of the cages (E. Gilinsky, personal observation); this greater food supply for grazers might account for the higher densities found in the open pond. Calmer water conditions and increased sedimentation within the cages does not seem likely, as that would tend to increase rather than decrease benthic densities within the enclosures (Kajak 1964). At any rate, differences between the cages and the natural pond did not enter into the actual design of the experiment, in which all comparisons were made between data taken within cages. The fact that drastic differences in densities or number of species did not occur in enclosures vs. the open pond is assurance that a natural benthic pond community was being considered in this study.

\section{Sampling program}

Samples of the macroinvertebrate community were usually taken at 4-wk intervals during the period from October 1978 through September 1979. As the fish and heterogeneity treatments were established in late August 1978 , there was a 6 -wk period of acclimation prior to sampling. All sampling was performed from a small boat. Two replicate samples per cage were taken each month. The exact sampling locations within a cage were determined from a random number table. No location (either benthos or rope plant) was sampled more than once.

Artificial macrophytes were lifted from the bottom either with a long pole with hook attachments, or by hand when accessible. A dip net (mesh size $1 \mathrm{~mm}$ ) was immediately placed underneath the rope plant and brought to the surface. This lifting technique minimized any disturbance of the benthic sediments. During most of the sampling period the cage bottom was clearly visible and no obvious movement of the sediments or clouding of the water occurred as the plants were lifted. After rinsing the periphyton and associated invertebrates off the rope, each strand of the rope plant was checked by hand for additional animals, particularly those that mined within the braided rope. The periphyton was washed through a number 50 sieve (mesh size $0.3 \mathrm{~mm}$ ) and preserved in $75 \%$ ethyl alcohol. The washed rope plant was then replaced in its former position.

Bottom sediment samples were taken with an Ekman dredge mounted on a releasing pole. The dredge samples an area of $0.023 \mathrm{~m}^{2}$. Over the course of the experiment only $7.6 \%$ of the bottom area of each cage was sampled. In high heterogeneity cages the artificial macrophyte was sampled first, after which the dredge sample of the underlying sediment was taken. Dredge samples were washed through a series of sieves, culminating in a number 50 sieve. Samples were preserved in $75 \%$ ethyl alcohol.

At the laboratory all samples were stained with Rose Bengal to aid in sorting. Benthic samples were initially examined by eye to remove larger organisms; then the samples were split into smaller volumes for examination under a dissecting microscope. Artificial macrophyte samples were halved and also examined under a dissecting microscope. All macroinvertebrates were removed from the samples and enumerated and identified to the lowest taxonomic level possible.

\section{Data analysis}

Initially, the data on macroinvertebrate densities and number of species were tested for homogeneity of variances using the $F_{\max }$ test (Sokal and Rohlf 1969). The results of the $F_{\max }$ tests on densities showed that the variances were nonhomogeneous over the year. Therefore a $\log (n+1)$ transformation (Sokal and Rohlf 1969) was used on all density data before further analysis. With regard to the species richness data, (number of species per sample) the initial $F_{\max }$ test was not significant $(P>.05)$, indicating that in this case the variances were homogeneous. Therefore no transformation was performed on the species richness data.

Two-way analyses of variance were performed on the data in order to consider the effects of fish predation and heterogeneity and the interactions between them. The design of the experiment allowed the following main effects and interactions to be tested in the ANOVA: fish predation $(\mathrm{df}=2)$, heterogeneity $(\mathrm{df}=1)$, block $(\mathrm{df}=2)$, fish predation $\times$ heterogeneity $(\mathrm{df}=2)$ and any block interactions. However, it was found that in the majority of cases the block effect was not significant, and in all cases its inclusion as a main effect did not change the significance of the other main effects. Therefore block and all its interactions have been omitted as a main effect and included in the error term (Snedecor and Cochran 1967). The analyses of variance were performed on the data grouped by season, according to traditional seasonal divisions (Fall = October-December 1978; Winter = January, March 1979; Spring = April and May 1979; Summer = June, July, September 1979). February and August are omitted because no samples were taken in these months. This seasonal division is appropriate as both fish feeding and the life cycles of the aquatic insects are seasonally influenced.

The ANOVAs were performed on total macroinvertebrate numbers and on the total number of species. In addition, the organisms were grouped both taxonomically and ecologically for further analysis in order to elucidate any group-specific responses. ANOVAs for each group were performed on benthic individuals (BENTHOS) in both high-heterogeneity and low-heterogeneity treatments for the three fish treatments, and separately on individuals found on the artificial macrophytes in heterogeneity cages under the various fish treatments (PLANT). In this manner potential differences in the responses of organisms in the benthic sediments and on the rope plants were examined. StudentNewman-Keuls (SNK) multiple-range tests (Steel and Torrie 1960) were performed on any treatments that 
TABLE 1. Macroinvertebrate taxa collected from Botany Pond ( ${ }^{*}$ denotes most abundant taxa).

\begin{tabular}{|c|}
\hline 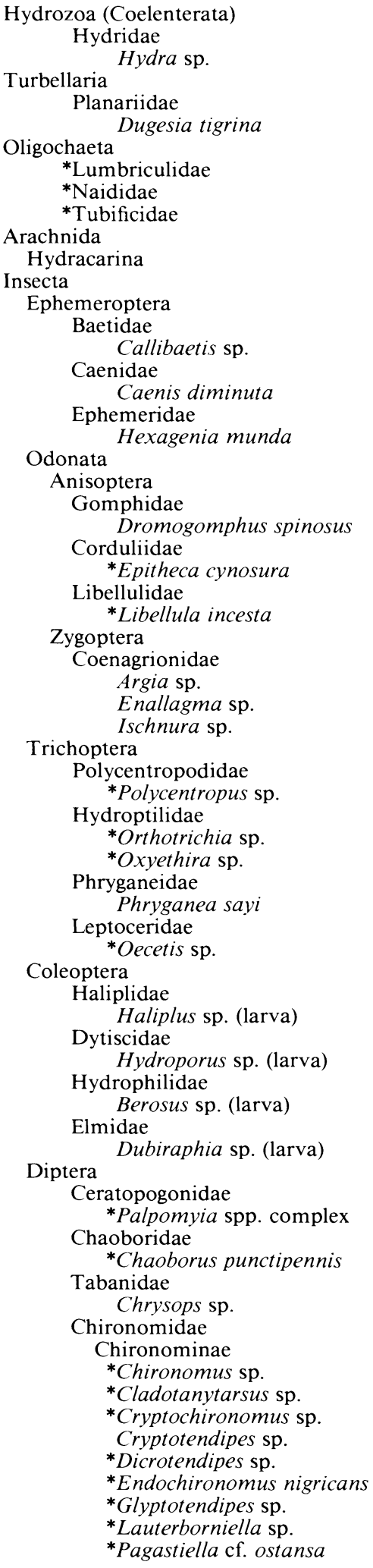 \\
\hline
\end{tabular}

TABle 1. Continued.

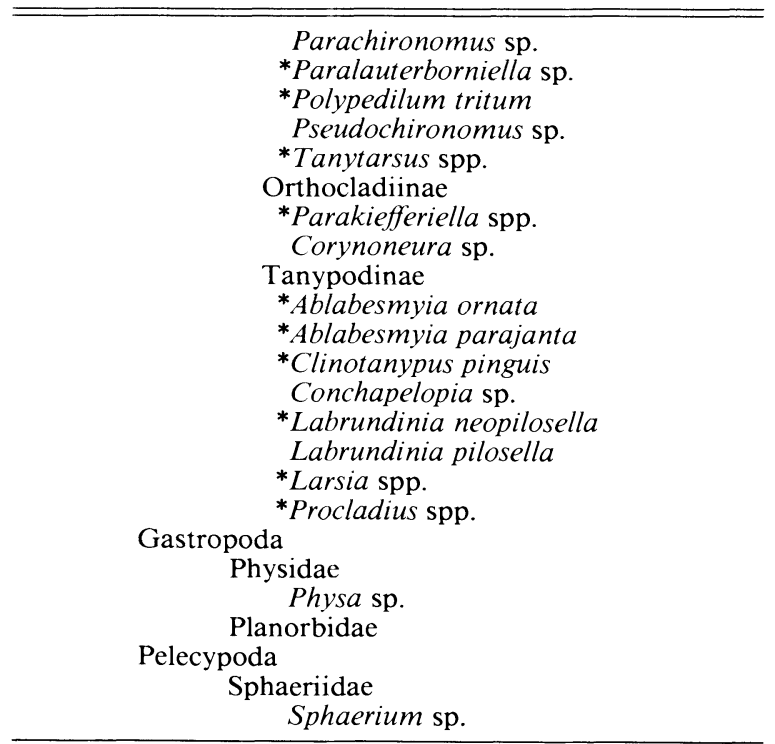

showed significance under the ANOVA to partition significant differences $(P \leq .05)$ among the treatment levels.

\section{RESULTS}

\section{Species richness}

A list of all macroinvertebrates found in the littoral zone of Botany Pond during the course of this study is given in Table 1. These species are typical for a Piedmont pond benthic community. The most abundant species in terms of frequency of occurrence and density are denoted by an asterisk. A total of 54 taxa were found in the benthic littoral zone of the pond; 29 of these can be considered abundant species. Approximately $50 \%$ of all taxa were dipteran larvae. The mean densities of all species grouped according to fish predation and heterogeneity levels can be found in Gilinsky (1981).

The number of macroinvertebrate species found was significantly affected by fish predation and heterogeneity. Fish predation had an impact (ANOVA, $P<$ $.01)$ on the mean number of benthic species occurring in the fall and winter, with an average of 15 species found in fish predation treatments, vs. an average of 10 species in fish exclusion cages. During the spring, fish predation had no effect on benthic species number, but by late summer fish predation resulted in a significantly lower (ANOVA, $P<.01$ ) mean number of species (8-10 species) when compared to fish exclusion treatments (about 12 species). Conversely, fish predation did not affect the number of species found on the rope plants.

The effects of heterogeneity on species richness were quite striking, as can be seen in Fig. 1, in which the 

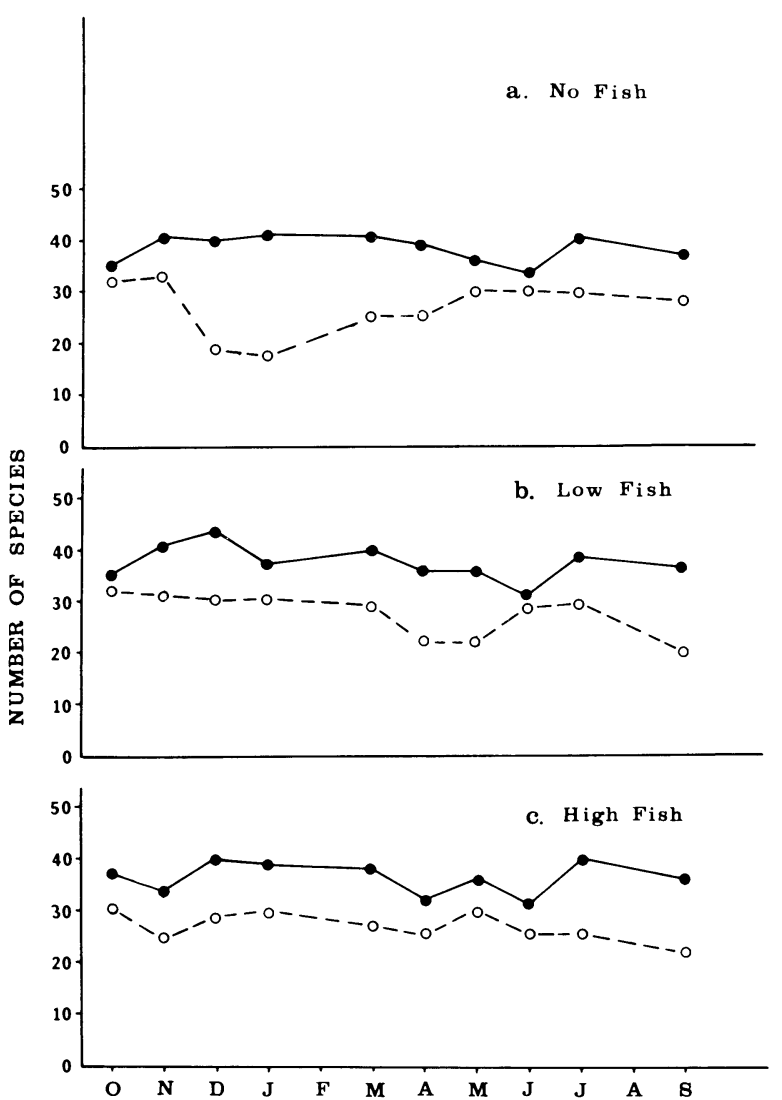

FIG. 1. Macroinvertebrate species richness (no. species per sample) grouped by fish predation and spatial heterogeneity treatments. Sampling interval varied from 4 to $6 \mathrm{wk}$ depending on the season. High-heterogeneity; $\bigcirc--O$ Lowheterogeneity.

number of species per sampling period is compared between high-heterogeneity cages and low-heterogeneity cages. In all cases, high-heterogeneity treatments had considerably more species than low-heterogeneity treatments (ANOVA, $P<.001$ ). These results show that the artificial macrophytes enhanced the number of macroinvertebrate species, perhaps by providing a different kind of habitat. Some of the species found more often in high-heterogeneity than low-heterogeneity cages include the mayfly Caenis diminuta, the damselfly Enallagma sp., the caddisfly Polycentropus sp., and the molluscs Physa sp. and Sphaerium sp., all fairly minor littoral-zone species. In addition, some dominant chironomids such as Ablabesmyia parajanta, A. ornata, Labrundinia neopilosella, Endochironomus nigricans, Dicrotendipes sp. and Glyplotendipes $\mathrm{sp}$. were more prevalent in the high-heterogeneity cages (Gilinsky 1981).

\section{Macroinvertebrate density}

Fish predation had a significant impact on total benthic macroinvertebrate densities in the fall $(F=11.29$,
$P<.001)$ and winter $(F=3.45, P<.05)$ months. As shown in Fig. 2, in these two seasons both low and high fish predation resulted in higher benthic densities than did fish exclusion (SNK, $P<.05$ ). Fish predation had no significant impact on benthic densities in the spring and summer. On the artificial macrophytes the effects of predation were significant in the winter $(F=$ $7.29, P<.001)$ with low fish density resulting in the highest macroinvertebrate densities, and in the spring $(F=3.67, P<.05)$, when May densities in fish exclusion cages were the greatest (Fig. 2; SNK, $P<.05$ ).

During all months, high-heterogeneity treatments (Fig. 2b and 2c combined) had more macroinvertebrates than low-heterogeneity treatments (Fig. 2a), indicating the importance of the macrophytes as an additional habitat. Considering only the benthos, the effects of added heterogeneity were significant for all seasons. Benthic densities in low-heterogeneity cages were $\approx 1.5$ times as great as densities in high-heterogeneity cages (Fig. 2a vs. 2b). This result suggests that certain macroinvertebrates may leave the benthos for the rope plants when they are present.

In order to consider more specific responses to the experimental manipulations, it is necessary to consider the effects of predation and heterogeneity on each of the major species groups found in the pond. What follows is a more detailed examination of the results along taxonomic and ecological lines.

\section{Trichoptera}

The caddisfly species present in the littoral zone of the pond included the herbivores Oxyethira sp., Orthotrichia sp., and Phryganea sp., and the nonobligate predators Oecetis sp. and Polycentropus sp., all of which cling and climb on the pond bottom and on macrophytes (Merritt and Cummins 1978). Mean benthic densities ranged from a low of $<100$ individuals $/ \mathrm{m}^{2}$ in the early spring to highs between 400 and 800 individuals $/ \mathrm{m}^{2}$ in the fall. Caddisfly densities on the artificial macrophytes averaged 200 individuals $/ \mathrm{m}^{2}$ of plant surface area by the end of the experimental period.

Fish predation had no significant $(P>.05)$ effect on trichopteran densities in the sediments or on the macrophytes. Benthic densities were relatively unaffected by the added environmental complexity.

\section{Odonata}

The only abundant odonates found during the experimental period were the dragonfly larvae Epitheca cynosura and Libellula incesta. The densities of these invertebrate predators fluctuated widely from month to month, primarily due to their patchy distribution. Benthic densities fluctuated between 0 and 200 individuals $/ \mathrm{m}^{2}$ over the course of a year, while odonates found on the plants had densities between 0 and 50 individuals $/ \mathrm{m}^{2}$ of plant surface area. In all cases fish predation showed no significant $(P>.05)$ effect on 
odonate densities, probably due to these large fluctuations, as well as the lack of an abundant odonate fauna in the pond. However, for almost all months more odonates were found in the fish exclusion cages (Gilinsky 1981). The added heterogeneity had no effect on benthic odonate densities.

\section{Chironomidae}

The chironomids are a very diverse group, with 18 common species and several rare ones found in the littoral zone of Botany Pond. Most of the chironomids found in the pond belong either to the predaceous subfamily Tanypodinae, or the more herbivorous/detritivorous subfamily Chironominae. However, several different lifestyles occur within these taxonomic groups. Based on information obtained from Merritt and Cummins (1978) on the habits and trophic relationships of chironomid larvae, I formulated six ecological groupings of the major chironomid species found in Botany Pond.

Clinotanypus pinguis was the dominant benthic predaceous chironomid in the system. This burrowing chi-

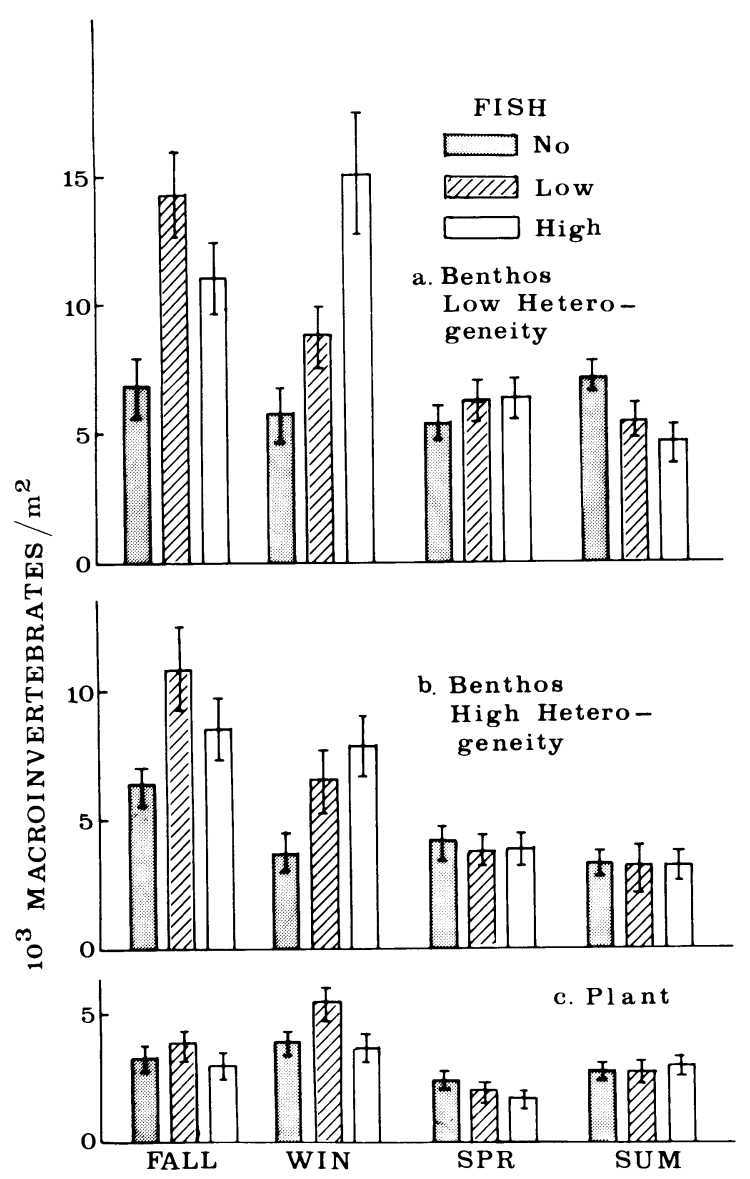

FIG. 2. Mean densities of total macroinvertebrates (a) in benthos in low-heterogeneity cages; (b) in benthos in highheterogeneity cages; (c) on plants in high-heterogeneity cages.

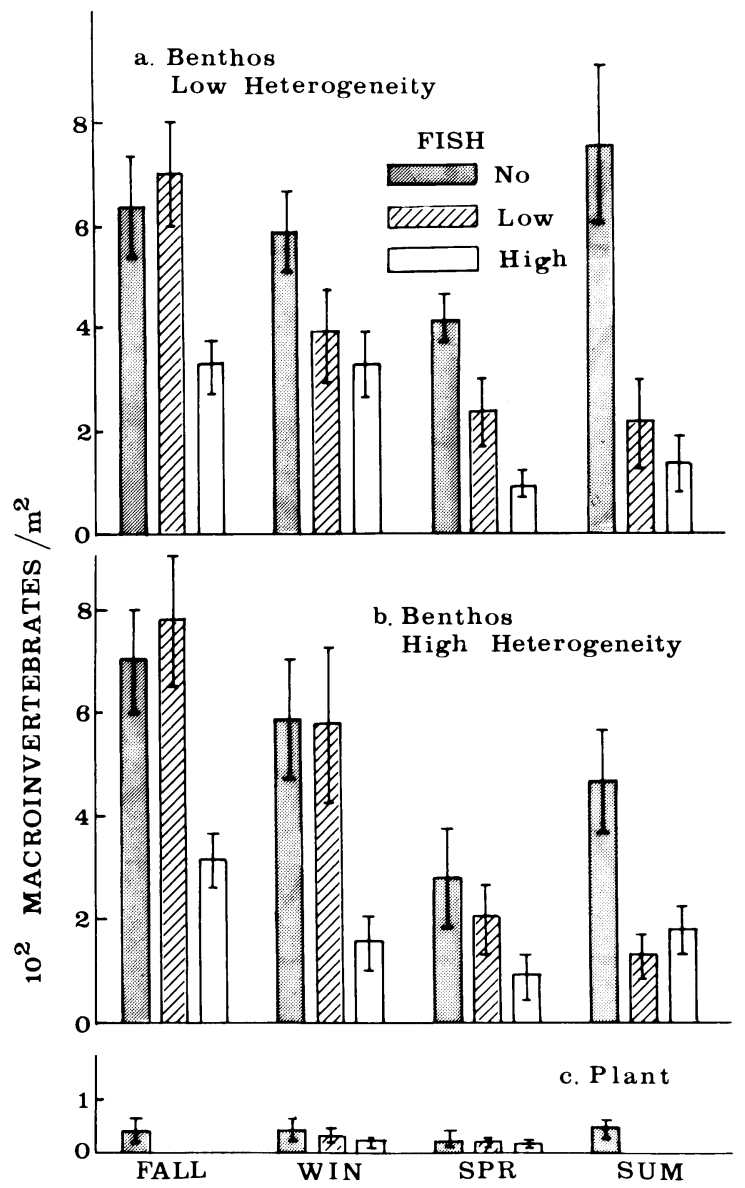

FIG. 3. Mean densities of Clinotanypus pinguis (a) in benthos in low-heterogeneity cages; (b) in benthos in high-heterogeneity cages; (c) on plants in high-heterogeneity cages.

ronomid showed the most striking fish predation effect (Fig. 3). In the fall and winter, zero and low fish densities resulted in the highest Clinotanypus densities (SNK, $P<.001$ ), and no predation gave the highest densities during the spring and summer (SNK, $P<$ $.001)$. As expected, densities on macrophytes were very low throughout the study (Fig. 3). Thus Clinotanypus showed a strong negative response to fish predation. In addition, during all seasons benthos with or without macrophytes harbored similar densities (Fig. 3a vs. 3b). The lack of a heterogeneity effect reflects the fact that the plants were not an important habitat for Clinotanypus. It is noteworthy that during the winter the fish $\times$ heterogeneity interaction term was significant $(F=3.48$, $P<.05)$, indicating that the effects of fish predation were more pronounced in the less complex environment.

Procladius spp., the other major predaceous benthic chironomid species, showed quite a different response to bluegill predation (Fig. 4). Fish predation had a significant impact on densities of this sprawler-type predaceous chironomid only during the fall $(F=9.95, P<$ 


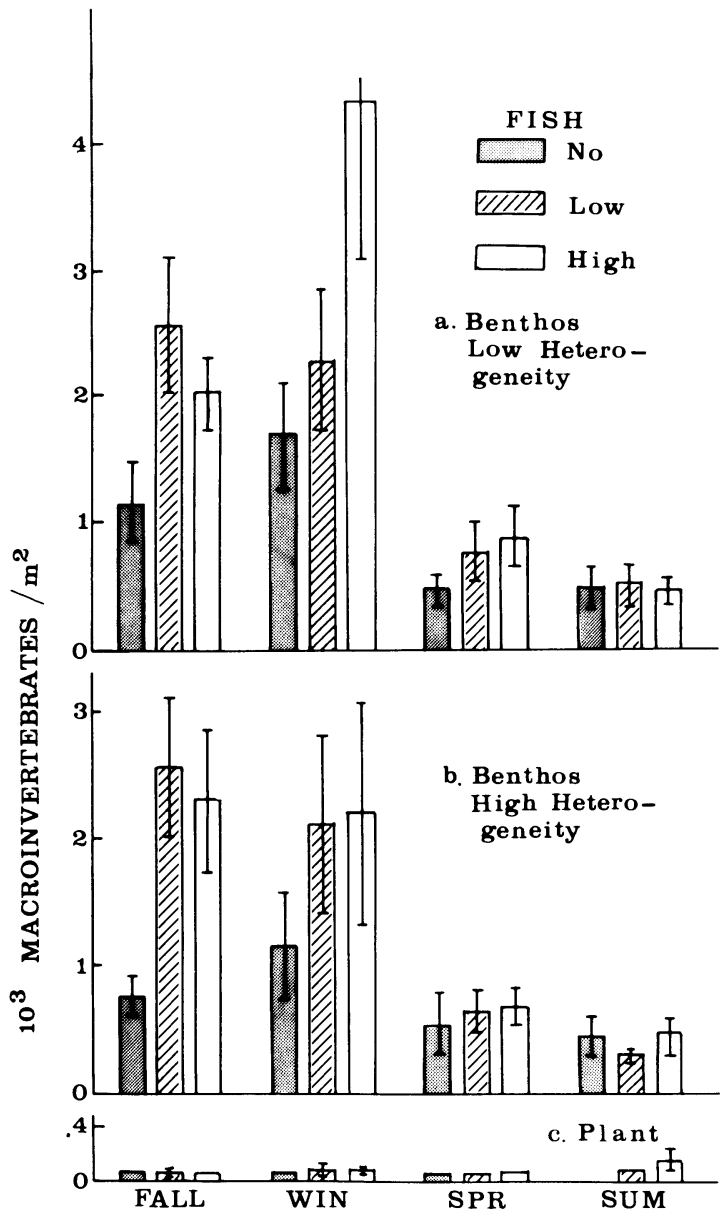

FIG. 4. Mean densities of Procladius spp. (a) in benthos in low-heterogeneity cages; (b) in benthos in high-heterogeneity cages; (c) on plants in high-heterogeneity cages.

$.001)$, when fish inclusion yielded higher densities than fish exclusion. During the remainder of the year Procladius densities were equal across all fish treatments (Fig. 4). Procladius was not common on the rope plants and the effect of heterogeneity on their density was not significant.

The other members of the subfamily Tanypodinae belong to a group of predatory chironomids that are abundant on macrophytes as well as being present in the sediments. The dominant members of this macrophyte-dwelling predator group include Ablabesmyia parajanta, Labrundinia neopilosella, and Larsia spp. Also in this group, but occurring less abundantly, were Ablabesmyia ornata, Labrundinia pilosella and Conchapelopia sp.

Fish predation had a significant impact on the density of the macrophyte-dwelling predaceous chironomids only during the summer $(F=3.61, P<.05)$, when fish exclusion and low fish treatments had greater densities of this chironomid group than did high fish treatments (Fig. 5). During the winter fish predation significantly affected densities on the plants $(F=3.53$, $P<.05$ ), with low-fish treatments yielding higher densities than high-fish or fish-exclusion treatments (Fig. 5). Heterogeneity had a marked effect on benthic densities of this group during the fall, winter, and summer seasons. In all cases bare sediments harbored higher densities of these macrophyte-dwelling predators than did plant-covered sediments (Fig. 5a vs. 5b; ANOVA, $P<.05)$. Perhaps individuals in this group were leaving the sediments for the macrophytes when this habitat was available.

The major species belonging to the subfamily Chironominae fall into three ecological groups. One group (benthic herbivores) contains Tanytarsus spp., Polypedilum tritum, Cladotanytarsus sp., and Pagastiella cf. ostansa; all are primarily herbivores that occur more abundantly in the benthic sediments. Another group of primarily tube-building herbivores includes Paralauterborniella sp., Lauterborniella sp., and Cryptochironomus sp. A third group consists of tube-building chironomids that occur sporadically in the benthos but quite consistently on the artificial macrophytes, where they were observed both on the surface and mining within the braided strands of the plants. These tubebuilding miners include Dicrotendipes sp. and the less

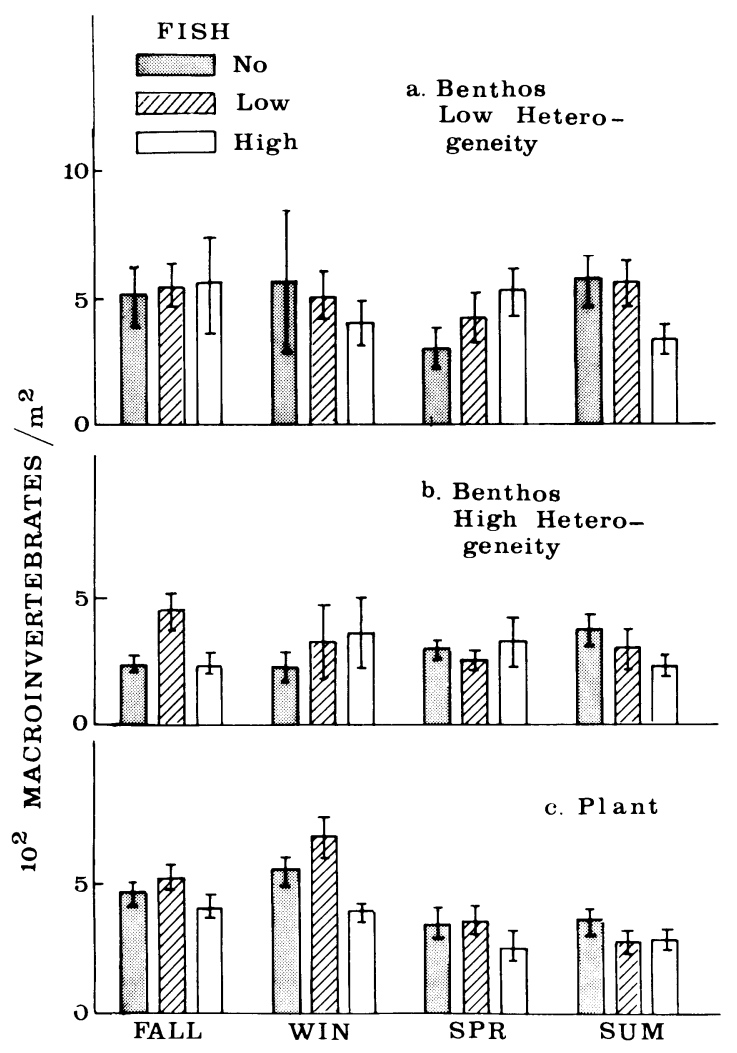

FIG. 5. Mean densities of the macrophyte-dwelling predaceous Tanypodinae chironomid group (a) in benthos lowheterogeneity cages; (b) in benthos in high-heterogeneity cages; (c) on plants in high-heterogeneity cages. 
abundant Endochironomus nigricans and Glyptotendipes $\mathrm{sp}$

The effects of fish predation on the benthic herbivore group of chironomids varied according to season (Fig. $6)$. In the fall $(F=5.10, P<.01)$ and winter $(F=15.99$, $P<.001$ ), high- and low-fish treatments yielded greater benthic densities than the no-fish treatment. Fish predation had no significant effect during the spring. By summer the fish-exclusion cages had the highest benthic densities of this group $(F=4.85, P<.01)$. Fish predation had no striking impact on densities of the benthic herbivores found on the artificial macrophytes, although during the winter, fish inclusion cages had higher chironomid densities $(F=9.06, P<.001)$. The effects of heterogeneity on benthic herbivore chironomid densities were evident throughout the experiment; during all seasons benthos not covered by macrophytes had higher densities of this chironomid group (Fig. 6a vs. 6b). In contrast, for both the tube-building herbivore and tube-building miner chironomids, bluegill predation had no significant effects either on benthic or macrophytic densities. In addition, the added environmental complexity had no impact on benthic densities of these two chironomid groups.

\section{Summary of major findings}

Fig. 7 summarizes the major patterns of benthic macroinvertebrate response to fish predation found in this study. In Pattern A the effects of fish predation on macroinvertebrate density switch with season. As shown by the benthic herbivore chironomid group, bluegill predation initially leads to an increase and then a decrease in density compared to the fish exclusion treatment. In addition, the mean number of species found in response to fish predation followed Pattern A. Pattern B is similar to Pattern A in that fish predation initially enhances density; however, in Pattern $\mathrm{B}$, predation had no effect during the spring and summer months. Procladius sp. followed this response pattern. Pattern $\mathrm{C}$ shows a negative response to fish predation; here fish exclusion results in higher densities throughout the year. Clinotanypus sp., the dominant predaceous chironomid in the pond, showed this Pattern $\mathrm{C}$ response most strongly, while the macrophytedwelling predaceous chironomids responded negatively to bluegill predation during the summer only. Finally, in Pattern D, fish predation had no significant effect on macroinvertebrate densities over the entire experimental period. The trichopterans, odonates, and both tube-building herbivore and tube-building miner chironomids all followed the Pattern D response.

In general, bluegill predation had no significant impact on macroinvertebrate densities on the artificial macrophytes, suggesting a refuge value for the plants. In addition, the increased complexity had important implications for species richness and densities. Treatments containing macrophytes had both more species and more individuals, a result not surprising in view

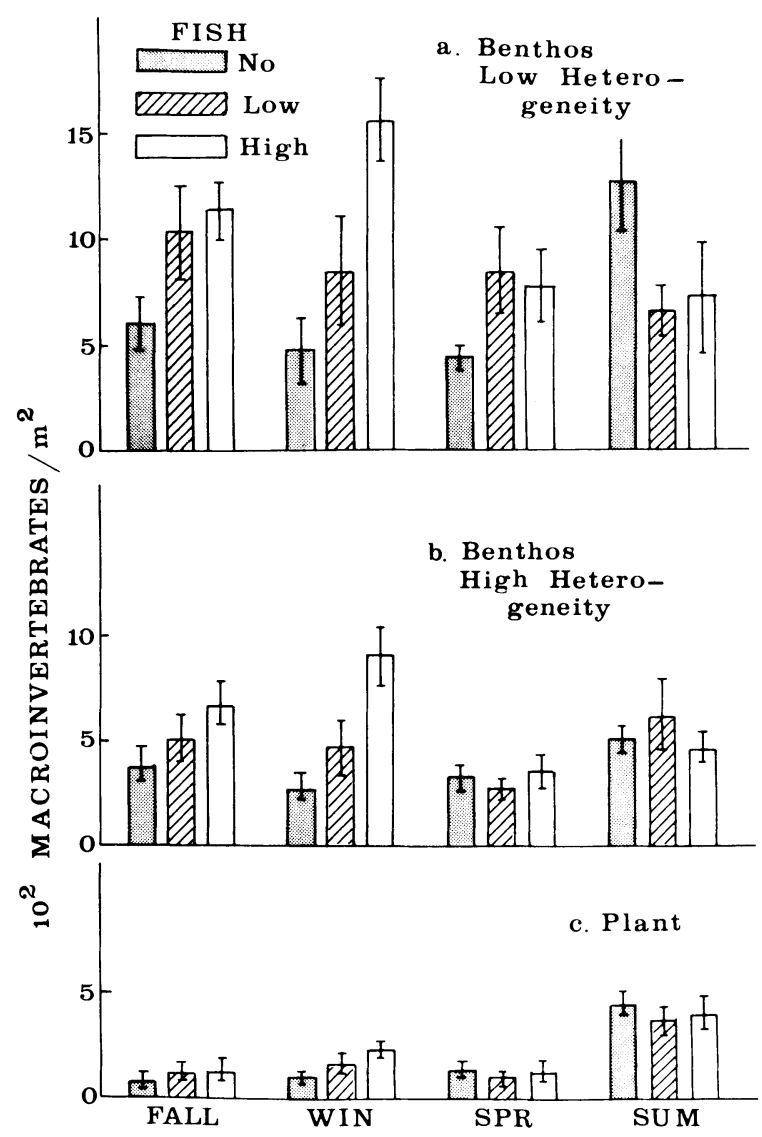

FIG. 6. Mean densities of the benthic herbivore chironomid group (a) in benthos in low-heterogeneity cages; (b) in benthos in high-heterogeneity cages; (c) on plants in highheterogeneity cages.

of the added substrate space and new habitat that was available in the heterogeneity cages. A less expected finding was that for several chironomid groups, sediments not covered by macrophytes had greater densities than did sediments covered by the artificial plants, indicating the possibility of migration onto the plants as they became available.

\section{DISCUSSION}

From this experiment, it is clear that fish predation plays a role in structuring the benthic macroinvertebrate community in the pond littoral zone. However, the nature of its impact varies with species, season, and spatial complexity.

The seasonal influence on the effects of fish predation on benthic densities is evident when considering two of the four response patterns to bluegill predation, Patterns $\mathrm{A}$ and $\mathrm{B}$. The first question raised by these response patterns concerns the switch in fish predation effects over the year. Why would fish predation lead to increased prey abundance in the fall and winter but decreased abundance in the summer? Studies on blue- 

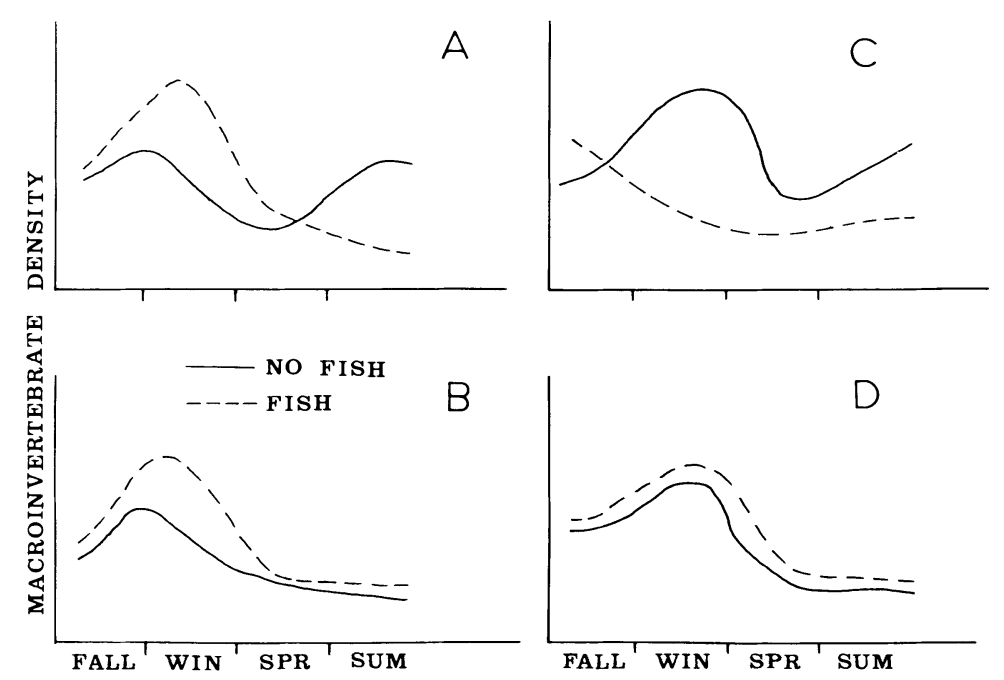

FIG. 7. Patterns of fish predation effects on macroinvertebrate density.

gill populations have shown that their reproduction and growth is limited to the spring and summer months (Gerking 1962). Consequently, their feeding activity is severely reduced during the winter season (Moffett and Hunt 1943), whereas over the course of the summer they have been known to consume up to six times their own mass, the majority of their diet consisting of benthic macroinvertebrates (Gerking 1964). Pieczynski (1973) found that the effects of fish feeding on chironomid populations were most pronounced in the summer. Hurlbert and Mulla (1981), in a study of pond plankton communities, found that the impact of mosquitofish predation was less during the winter, when fish feeding rates were lower than in the summer. Hall et al. (1970) found that for their major chironomid species, bluegill predation caused an increase in density in the spring but a decrease in density in the summer, a result quite similar to this study. Most other studies on the effects of fish predation on benthic macroinvertebrates have not shown this seasonal switch in predation effects, primarily because they were performed only during the summer months (Hayne and Ball 1956, Hruska 1961, Korinkova 1967, Kajak 1977, Andersson et al. 1978, Crowder and Cooper 1982). In fact, the only year-long experiment was done by Thorp and Bergey $(1981 a)$. They did not find any significant seasonal patterns. However, they had no assessment of actual predation intensity and they performed their experiments in 3-mo blocks rather than continuously over the year.

It appears that in this study predation intensity changed over the course of the year even though fish density remained constant. During the fall and winter seasons, bluegill feeding was reduced, so predation intensity was less than during the summer, when the bluegill fed quite voraciously. The lower predation in- tensity led to increased abundances of many species, but the high summer predation intensity caused decreased macroinvertebrate abundances.

The second question deals with the possible causes for fish predation initially leading to increased prey densities. One possible explanation is that the bluegill are feeding on a dominant invertebrate predator or competitor, as occurs in the rocky intertidal system (Paine 1966, 1969, 1971). In fact, the predaceous chironomid Clinotanypus pinguis shows increased densities in the absence of fish predation throughout most of the year (Fig. 3), indirect evidence that the bluegill are feeding on this species. Clinotanypus is particularly susceptible to bluegill predation, as it tends to swim in the water column (Davies 1976, S. C. Mozley, personal communication) where bluegill often feed (Keast and Welsh 1968, Mozley 1968). Since Clinotanypus is known to feed on the other chironomid species (Roback 1969, Merritt and Cummins 1978), decreases in Clinotanypus density in fish treatments could be responsible for increased abundance of its prey, notably the noncarnivorous chironomids. Thorp and Bergey $(1981 b)$ also found that several nonpredatory chironomid species increased under fish predation, although they did not find an accompanying decrease in predatory chironomids. In their study, they rule out the possibility that predaceous chironomids were replacing the role of vertebrate predators in the pond system.

Clinotanypus might also be in competition with the other dominant predaceous chironomid in this system, Procladius spp. and the macrophyte-dwelling predator group. Although competition between Coelotanypus sp., a close relative of Clinotanypus, and Procladius sp. in lake benthic sediments has been documented (D. $\mathrm{R}$. Lenat, personal communication), no significant correlations were found between any of the three chiron- 
omids in this study (Spearman Rank Correlation Coefficient, $P>.05$ ). Similarly, the lack of significant correlations also suggests that predation between these chironomids was not important here, although studies of their dietary preferences indicate that they often feed on each other as well (Roback 1969).

Another group of invertebrate predators found in this system are the odonates, represented most abundantly by the dragonflies Epitheca cynosura and $\mathrm{Li}$ bellula incesta. Although in this study the odonates showed no significant fish effects, there was a trend for densities to be greater in the absence of fish predation. Thorp and Bergey (1981 $a$ ) also found a nonsignificant trend for increased odonate densities in fish exclusion cages. However, in their experiments, Crowder and Cooper (1982) found that odonates inhabiting vegetation in ponds were removed by bluegill predators. The lack of clear differences found here might be explained by the results of Benke (1978), who found that fish exclusion did not necessarily lead to increased odonate densities; he attributed this to the tendency for large odonates to eat smaller odonates. It is well documented that odonates feed on other benthic macroinvertebrates, especially chironomid larvae (Pritchard 1964, Bay 1974). Benke (1978) found that chironomids belonging to the subfamily Tanypodinae (represented in my study by Ablabesmyia spp., Larsia spp., Labrundinia spp., Procladius spp., and Clinotanypus pinguis) were a common dietary item for pond dragonfly larvae. As additional evidence for the importance of odonates as invertebrate predators, Menzie (1978) and Crowder and Cooper (1982) both found that fish exclusion led to increased densities of certain odonates but decreased densities of their chironomid prey.

Thus it is possible that a vertebrate predator, feeding on several invertebrate predators, might be responsible for actually decreasing predation pressure on the majority of benthic macroinvertebrates, In the summer, when bluegill feeding activity increases, vertebrate predation intensity is severe enough to limit the numbers of all invertebrate prey.

In addition, bluegill predation might increase benthic densities by their feeding on one or several competitive dominants. The potential existence of competition between benthic macroinvertebrates cannot be ignored. My study had too many covariables to consider competitive relationships; as mentioned previously, the effects of fish predation might obscure any possible relationships. Hall et al. (1970) found that an increased nutrient supply led to an increase in benthic macroinvertebrate standing crop, primarily through increased size and decreased generation time. This result would seem to indicate that the benthic food supply may be limiting in some cases. Hayne and Ball (1956) found that while fish predation decreased benthic standing crops, it increased benthic production. It is possible that the fish, through selective feeding, may alleviate competitive pressures and allow the poorer competitors to increase in density. Once predation intensity reaches a certain level, however, all populations suffer a similar mortality and numbers decrease.

The impact of fish predation on those populations found on the artificial macrophytes was somewhat different. Bluegill predation resulted in increased densities in the winter for the macrophyte-dwelling predator and benthic herbivore chironomid groups. The most striking result was that on the artificial macrophytes, fish predation had no significant effect over the year (Pattern D) for the majority of macroinvertebrate groups. In particular, the tube-building chironomids, which were quite abundant on the plants, showed no response to bluegill predation. In view of the fact that these chironomids often mined within the braided strands of the plants or remained within their tubes, this result is not surprising. Other chironomid groups for which fish predation on the rope plants was not significant are Procladius spp. and Clinotanypus pinguis, the latter species having shown a dramatic predation effect in the benthic sediments. In contrast, Crowder and Cooper (1982) found that bluegill predation significantly decreased macroinvertebrate biomass in pond vegetation. However, they did find that, similar to this study, some chironomids actually increased under fish predation.

It certainly seems that fish predation was not as effective on the artificial macrophytes as it was in the benthos, and that the plants do serve as a spatial refuge from predation. The most convincing evidence for this would be significant fish $\times$ heterogeneity interactions in the ANOVA. This interaction was found to be significant during the winter for Clinotanypus, when the fish effect in the heterogeneity cages was less pronounced (Fig. 3). Clinotanypus, rather than using the artificial macrophytes as a substrate, swims within the water column, but is protected by the strands of the plants; they are thus less accessible to the bluegill. These results suggest that the macrophytes might serve as a spatial refuge from predation, and that the increased structural complexity decreases predator efficiency. This goes along with the theoretical conclusion that increased spatial complexity provides refuges from predation (Smith 1972, Murdoch and Oaten 1975) as well as the experimental observations that habitat complexity decreases predator efficiency (Glass 1971, Ware 1972, Hall and Hyatt 1974, Nelson 1979, Coen et al. 1981, Crowder and Cooper 1982).

The added heterogeneity led to greater species richness in cages that contained artificial macrophytes (Fig. 1). In addition, there were more total individuals of all species combined in the heterogeneity treatments. This might be a response merely to additional substrate space, or perhaps the new available habitat allowed for more or different feeding strategies, as predicted by Smith (1972). Other investigators have also found 


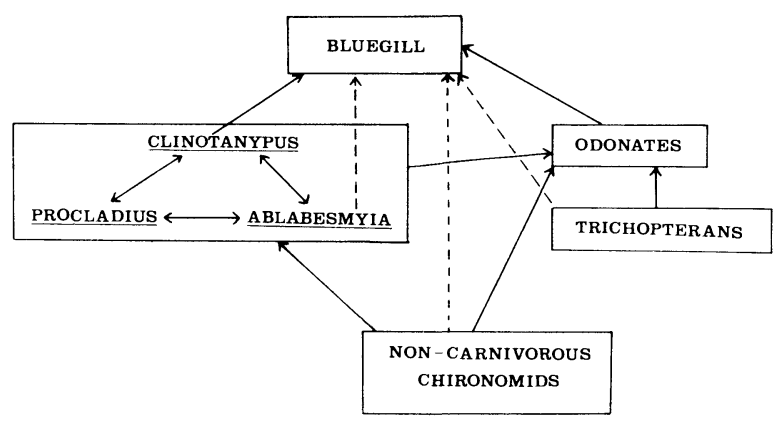

Fig. 8. Major predator pathways in the littoral zone of Botany Pond.

greater invertebrate abundances within macrophyte beds (Gerking 1962, Soszka 1975, Menzie 1978).

Comparing benthic densities in high-heterogeneity vs. low-heterogeneity treatments, I found that uncovered sediments had higher densities and greater species richness than sediments covered by plants. This suggests that certain benthic species (notably Ablabesmyia spp. and the benthic herbivore chironomid group) $\mathrm{mi}$ grate onto the artificial macrophytes when this new habitat becomes available. Several investigators (Mason and Bryant 1975, Soszka 1975, Menzie 1980) have also noted the movement of benthic macroinvertebrates onto macrophytes during the spring and summer when macrophyte abundance is at its peak. Thus, the macrophytes might increase species richness by providing a new habitat and serving as a potential refuge from fish predation.

In general, these conclusions lend support to the theory of community structure as developed in the rocky intertidal system (Paine 1966, Dayton 1971, Connell 1975 , etc.). This theory asserts that a keystone predator can increase both the species diversity and overall density within a community by preying on the competitive dominant within the system. In this manner the keystone predator prevents resource monopolization by one or a few species in the community.

However, in my system, although densities of some species did increase under fish predation, I found no real trend for species richness to change dramatically according to fish predation treatment. This indicates that the bluegill sunfish might be an important predator but not a keystone predator, as previously hypothesized by Hall et al. (1970). One possible reason, raised by Peterson (1979) for marine soft bottom communities, is that the absence of predation might decrease overall densities but not change species diversity if competition manifests itself through decreased growth rates and reproductive effort rather than through mortality. Thus, the predator might still be preying on the competitive dominants, but the community response would be an increase in growth rates of several species rather than an increase in species diversity. More likely, as shown by my experiment, it is an assemblage of vertebrate and invertebrate predators, rather than a single keystone predator, that is important in controlling benthic community structure.

A schematic representation of the major predator pathways in the littoral zone of Botany Pond, as interpreted from my experimental results, is given in Fig. 8. As can be seen in this diagram, several invertebrate groups, as well as the bluegill sunfish, play an important predatory role in the system. The bluegill feed primarily on the predaceous chironomid Clinotanypus and the odonates; in times of intense feeding, they also concentrate on Ablabesmyia spp. (also predaceous chironomids), several groups of noncarnivorous chironomids, and the trichopterans.

The predatory relationships among the invertebrates are also important, and their intensity is most likely affected by bluegill predation as well. The odonates are major predators on trichopterans, noncarnivorous chironomids, and the predaceous chironomids. The relationships among the predaceous chironomids are quite complex. They are potential competitors in that they feed on a common resource, notably the noncarnivorous chironomids (and also oligochaetes and zooplankton). In addition they may feed on each other, thus complicating any competitive relationships. The intensity of fish feeding may alter these interrelationships as the bluegill feed primarily on Clinotanypus and also on the macrophyte-dwelling predaceous chironomids under intense summer feeding. The relationships among these invertebrate predators must be clarified before a clear picture of community structure in the littoral zone emerges.

In summary, predation does seem to be an important organizing process in benthic community structure in the pond littoral zone. Less intense fish predation leads to increased prey abundance, as in the rocky intertidal. However the fish, rather than preying on potential competitors, seem to feed selectively on the major invertebrate predators in the system. Perhaps it is these invertebrate predators that are actually influencing the remainder of the benthic community. More intense fish predation results in decreased prey abundance, as in marine soft bottom communities. In this case, the predator population seems to be feeding on a wider range of prey populations, thus causing a general decline in the entire benthic community. Spatial heterogeneity alters the effects of predation by lessening its impact on the benthic community, both through the provision of a spatial refuge and by decreasing predator foraging efficiency. Further experimentation on the influence of invertebrate predators, the existence of competitive relationships between benthic macroinvertebrates, and the direct measurement of predator feeding intensity over the year are needed to clarify the factors controlling the organization of the benthic pond community. 


\section{ACKNOWLEDGMENTS}

I wish to thank members of the University of North Carolina Ecology group for their free exchange of ideas and an occasional "extra hand" in the field. The cooperation of the director and staff of the North Carolina Botanical Garden was appreciated. Dave Lenat kindly lent me his chironomid expertise in confirming my identifications. Stuart Hurlbert provided constructive comments on a draft of this manuscript. Many thanks to Nancy Parker for typing the manuscript. On a more personal level I thank my parents for their continued support. Foremost I thank my husband and number one field assistant, Len Smock, for his encouragement, technical assistance, and understanding. This research was supported by a Sigma-Xi Grant-In-Aid of Research and National Science Foundation grant DEB-77-24052. Funds for computer analysis were provided by the Department of Zoology at the University of North Carolina and the Virginia Commonwealth University Computer Center.

\section{Literature Cited}

Andersson, G., H. Berggren, G. Cronberg, and C. Gelin. 1978. Effects of planktivorous and benthivorous fish on organisms and water chemistry in eutrophic lakes. Hydrobiologia 59: 9-15.

Ball, R. C. 1948. Relationship between available fish food, feeding habits of fish and total fish production in a Michigan lake. Michigan State College Agricultural Experimental Station Technical Bulletin 206.

Ball, R. C., and D. W. Hayne. 1952. Effects of the removal of the fish population on the fish food organisms of a lake. Ecology 33:41-48.

Baumann, P. C., and J. F. Kitchell. 1974. Diel patterns of distribution and feeding of bluegill (Lepomis macrochirus) in Lake Wingra, Wisconsin. Transactions of the American Fisheries Society 103:255-260.

Bay, E. C. 1974. Predator-prey relationships among aquatic insects. Annual Review of Entomology 19:441-453.

Bell, S. S., and B. C. Coull. 1978. Field evidence that shrimp predation regulates meiofauna. Oecologia 35:141-148.

Benke, A. C. 1978. Interactions among coexisting predators - a field experiment with dragonfly larvae. Journal of Animal Ecology 47:335-350.

Brooks, J. L., and S. I. Dodson. 1965. Predation, body size, and composition of plankton. Science 150:28-35.

Coen, L. D., K. L. Heck, Jr., and L. G. Abele. 1981. Experiments on competition and predation among shrimps of seagrass meadows. Ecology 62:1484-1493.

Commito, J. A. 1976. Predation, competition, life-history strategies, and the regulation of estuarine soft-bottom community structure. Dissertation. Duke University, Durham, North Carolina, USA.

Connell, J. H. 1970. A predator-prey system in the marine intertidal region. I. Balanus glandula and several predatory species of Thais. Ecological Monographs 40:49-76.

. 1975. Some mechanisms producing structure in natural communities: a model and evidence from field experiments. Pages 460-490 In M. L. Cody and J. M. Diamond, editors. Ecology and evolution of communities. Harvard University Press, Cambridge, Massachusetts, USA.

Cooper, W. E. 1965. Dynamics and production of a natural population of a freshwater amphipod, Hyallela azteca. Ecological Monographs 35:377-394.

Crowder, L. B., and W. E. Cooper. 1982. Habitat structural complexity and the interaction between bluegills and their prey. Ecology 63:1802-1813.

Davies, B. R. 1976. The dispersal of Chironomidae larvae: a review. Journal of the Entomological Society of South Africa 39:39-62.
Dayton, R. K. 1971. Competition, disturbance, and community organization: the provision and subsequent utilization of space in a rocky intertidal community. Ecological Monographs 41:351-389.

Dodson, S. I. 1974. Zooplankton competition and predation: an experimental test of the size-efficiency hypothesis Ecology 55:605-613.

Etnier, D. A. 1971. Food of three species of sunfishes (Lepomis, Centrarchidae) and their hybrids in three Minnesota lakes. Transactions of the American Fisheries Society 100: 124-128.

Flemer, D. A., and W. S. Woolcott. 1966. Food habits and distribution of the fishes of Tuckahoe Creek, Virginia, with species emphasis on the bluegill, Lepomis m. macrochirus. Chesapeake Science 7:75-89.

Gerking, S. D. 1962. Production and food utilization in a population of bluegill sunfish. Ecological Monographs 32: 31-78.

. 1964. Timing and magnitude of the production of a bluegill sunfish population and its food supply. Internationale Vereinigung für theoretische and angewandte Limnologie, Verhandlungen 15:496-503.

, editor. 1978. Ecology of freshwater fish production. John Wiley and Sons, New York, New York, USA

Gilinsky, E. 1981. The role of predation and spatial heterogeneity in community structure: the experimental manipulation of a pond system. Dissertation. The University of North Carolina, Chapel Hill, North Carolina, USA.

Glass, W. R. 1971. Computer analysis of predation energetics in the largemouth bass. Pages 325-363 In B. C. Patten, editor. Systems analysis and simulation in ecology. Volume I. Academic Press, New York, New York, USA.

Hall, D. J., W. E. Cooper, and E. E. Werner. 1970. An experimental approach to the production dynamics and structure of freshwater animal communities. Limnology and Oceanography 15:839-928.

Hall, K. J., and K. D. Hyatt. 1974. Marion Lake (IBP)from bacteria to fish. Journal of the Fisheries Research Board of Canada 31:893-911.

Hardmann, J. M., and H. L. Turnbull. 1974. The interaction of spatial heterogeneity, predator competition and the functional response to prey density in a laboratory system of wolf spiders and fruit flies. Journal of Animal Ecology 43: 155-168.

Harper, J. L. 1969. The role of predation in vegetational diversity. In Diversity and stability in ecological systems. Brookhaven Symposium in Biology 22:48-61.

Hassell, M. P., and R. M. May. 1973. Stability in insect host-parasite models. Journal of Animal Ecology 42:693726.

Hayne, D. W., and R. C. Ball. 1956. Benthic productivity as influenced by fish predation. Limnology and Oceanography $1: 162-175$.

Heck, K. L., Jr., and T. A. Thoman. 1981. Experiments on predator-prey interactions in vegetated aquatic habitats. Journal of Experimental Marine Biology and Ecology 53: 125-134.

Hruska, V. 1961. An attempt at a direct investigation of the influence of the carp stock on the bottom fauna of two ponds. Internationale Vereinigung für theoretische and angewandte Limnologie 14:732-736.

Huffaker, C. B. 1958. Experimental studies on predation: dispersion factors and predator-prey oscillations. Hilgardia 27:343-383.

Huffaker, C. B., and C. E. Kennett. 1956. Experimental studies on predation: predation and cyclamen mite populations on strawberries in California. Hilgardia 26:191-222.

Hurlbert, S. H., and M. S. Mulla. 1981. Impacts of mosquito 
fish (Gambusia affinis) predation on plankton communities. Hydrobiologia 83:125-151.

Kajak, Z. 1964. Experimental investigations of benthos abundance on the bottom of Lake Sniardwy. Ekologia Polska Seria A 12:1-31.

1977. Factors influencing benthos biomass in shallow lake environments. Ekologia Polska 25:421-429.

Keast, A., and L. Welsh. 1968. Daily feeding periodicities, food uptake rates, and dietary changes with hour of day in some lake fishes. Journal of the Fisheries Research Board of Canada 25:1133-1144.

Kohn, A. J., and P. J. Leviten. 1976. Effect of habitat complexity on population density and species richness in tropical intertidal predatory gastropod assemblages. Oecologia 25:199-210.

Korinkova, J. 1967. Relations between predation pressure of carp, submerged plant development and littoral bottomfauna of Pond Smyslov. Rozpravy Ceskoslovenske Akademie Ved 77:35-62.

Macan, T. T. 1966. The influence of predation on the fauna of a moorland fishpond. Archiv für Hydrobiologie 61:432452.

- 1977. A twenty year study of the fauna in the vegetation of a moorland fishpond. Archiv für Hydrobiologie 81:1-24.

Macan, T. T., and A. Kitching. 1972. Some experiments with artificial substrata. Internationale Vereinigung für theoretische and angewandte Limnologie 18:213-220.

Mason, C. F., and R. J. Bryant. 1975. Periphyton production and grazing by chironomids in Alderfen Broad, Norfolk. Freshwater Biology 5:271-277.

Menzie, C. A. 1978. Productivity of chironomid larvae in a littoral area of the Hudson River estuary. Dissertation. City University of New York, New York, USA.

1980. The chironomid (Insecta: Diptera) and other fauna of a Myriophyllum spicatum L. plant bed in the lower Hudson River. Estuaries 3:38-54.

Merritt, R. W., and K. W. Cummins. 1978. An introduction to the aquatic insects of North America. Kendall/Hunt, Dubuque, Iowa, USA.

Meyer, K. A., and J. F. McCormick. 1971. Seasonal fluctuation of phytoplankton composition, diversity, and production in a freshwater lake. Journal of the Elisha Mitchell Society 87:127-138.

Moffett, J. W., and B. P. Hunt. 1943. Winter feeding habits of bluegills, Lepomis macrochirus Rafinesque, and yellow perch, Perca flavescens (Mitchell), in Cedar Lake, Washetenaw County, Michigan. Transactions of the American Fisheries Society 73:231-242.

Mozley, S. C. 1968. The integrative roles of the chironomid (Diptera: Chironomidae) larvae in the trophic web of a shallow five hectare lake in the Piedmont region of Georgia. Dissertation. Emory University, Atlanta, Georgia, USA.

Murdoch, W. W. 1977. Stabilizing effects of spatial heterogeneity in predator prey systems. Theoretical Population Biology 11:252-273.

Murdoch, W. W., and A. Oaten. 1975. Predation and population stability. Advances in Ecological Research 9:1-131.

Nelson, W. G. 1979. Experimental studies of selective predation on amphipods: consequences for amphipod distribution and abundance. Journal of Experimental Marine Biology and Ecology 38:225-245.

Orth, R. J. 1977. The importance of sediment stability in seagrass communities. Pages 281-300 in B. C. Coull, editor. Ecology of marine benthos. University of South Carolina Press, Columbia, South Carolina, USA.

Paine, R. T. 1966. Food web complexity and species diversity. American Naturalist 100:65-75.
1969. The Pisaster-Tegula interaction: prey patches, predator food preference, and intertidal community structure. Ecology 50:950-961.

1971. A short-term experimental investigation of resource partitioning in a New Zealand rocky intertidal habitat. Ecology 52:1096-1106.

Peterson, C. H. 1979. Predation, competitive exclusion, and diversity in the soft sediment benthic communities of estuaries and lagoons. Pages 233-264 in R. J. Livingston, editor. Ecological processes in coastal and marine systems. Plenum, New York, New York, USA.

Pieczynski, E. 1973. Experimentally increased fish stock in the pond type Lake Warniak XII. Numbers and biomass of the fauna associated with macrophytes. Ekologia Polska 21:595-610.

Pimentel, D., W. P. Nagel, and J. L. Madden. 1963. Spacetime structure of the environment and the survival of parasite-host systems. American Naturalist 97:141-167.

Pritchard, G. 1964. The prey of dragonfly larvae (Odonata: Anisoptera) in ponds in Northern Alberta. Canadian Journal of Zoology 42:785-800.

Reise, K. 1977. Predation pressure and community structure of an intertidal soft-bottom fauna. Pages 513-519 in B. F. Keegan, P. O. Cendeigh, and P. J. S. Boaden, editors. Biology of benthic organisms. Pergamon, Oxford, England.

Roback, S. S. 1969. Notes on the food of Tanypodinae larvae. Entomological News 80:13-18.

Smith, F. E. 1972. Spatial heterogeneity, stability and diversity in ecosystems. Transactions of the Connecticut Academy of Arts and Sciences 44:631-645.

Snedecor, G. W., and W. G. Cochran. 1967. Statistical methods. Iowa State University Press, Ames, Iowa, USA.

Sokal, R. R., and F. J. Rohlf. 1969. Biometry. W. H. Freeman, San Francisco, California, USA.

Sozska, G. J. 1975. The invertebrates on submerged macrophytes in three Masurian lakes. Ekologia Polska 23:371391

Steel, R. G. D., and J. H. Torrie. 1960. Principles and procedures of statistics with special reference to the biological sciences. McGraw-Hill, New York, New York, USA.

Thorp, J. H., and E. A. Bergey. 1981a. Field experiments on responses of a freshwater benthic macroinvertebrate community to vertebrate predators. Ecology 62:365-375.

Thorp, J. H., and E. A. Bergey. 1981b. Field experiments on interactions between vertebrate predators and larval midges (Diptera: Chironomidae) in the littoral zone of a reservoir. Oecologia (Berlin) 50:285-290.

Turner, W. R. 1955. Food habits of the bluegill Lepomis macrochirus macrochirus in eighteen Kentucky farm ponds during April and May. Transactions of the Kentucky Academy of Science 16:98-101.

Virnstein, R. W. 1977. The importance of predation by crabs and fishes on benthic infauna in Chesapeake Bay. Ecology 58:1199-1217.

- 1979. Predation on estuarine infauna: response patterns of component species. Estuaries 2:69-86.

Ware, D. M. 1972. Predation by rainbow trout (Salmo gairdneri): the influence of hunger, prey density and prey size. Journal of the Fisheries Research Board of Canada 29: 1193-1201.

Werner, E. E. 1977. Species packing and niche complementarity in three sunfishes. American Naturalist 111:553578

Young, D. K., and M. W. Young. 1977. Community structure of the macrobenthos associated with seagrass of the Indian River Estuary, Florida. Pages 359-382 in B. C. Coull, editor. Ecology of marine benthos. University of South Carolina Press, Columbia, South Carolina, USA. 